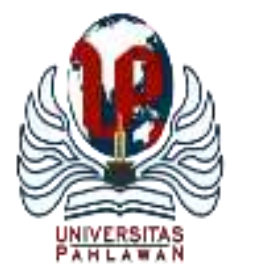

Edukatif : Jurnal Ilmu Pendidikan Volume 4 Nomor 1 Tahun 2022 Halm 28 - 37

EDUKATIF: JURNAL ILMU PENDIDIKAN

Research \& Learning in Education

https:/ledukatif.org/index.php/edukatif/index

\title{
Analisis Dampak Penggunaan Gadget terhadap Perkembangan Fisik dan Perubahan Perilaku pada Anak Sekolah Dasar
}

\author{
Siti Rahmi Jalilah \\ Universitas Islam Negeri Sunan Kalijaga Yogyakarta, Indonesia \\ E-mail : 20204082021@ student.uin-suka.ac.id
}

\begin{abstract}
Abstrak
Gadget merupakan salah satu alat komunikasi yang tidak bisa dipisahkan dalam kehidupan manusia. Sehingga di era saat ini gadget tidak hanya dikonsumsi oleh kalangan orang dewasa melainkan juga oleh kalangan anakanak. Maraknya penggunaan gadget pada anak dapat menghambat proses perkembang anak. Penelitian ini bertujuan untuk mengetahui dampak penggunaan gadget terhadap perkembangan fisik dan perilaku pada anak sekolah dasar. Metode dalam penelitian ini menggunakn metode kualitatif dengan pendekatan studi kasus. Data yang diperoleh melalui observasi dan wawancara. Setelah data dikumpulkan kemudian dilakukan reduksi data, penyajian data dan penarikan kesimpulan. Adapun kesimpulan dalam penelitian ini yaitu terjadinya ketergantungan dan kecanduan yang mengakibatkan kemalasan terhadap anak dalam beraktivitas, terganggunya kesehatan dari segi fisik, dan konsentrasi belajar semakin berukarang.
\end{abstract}

Kata Kunci : Dampak Gadget, Perkembangan Fisik dan Prilaku, Anak Sekolah Dasar.

\section{Abstract}

Gedjet is a communication tool that cannot be separated in human life. So that in the current era, gadgets are not only consumed by adults but also by children. The widespread use of gadgets in children can hamper the process of child development. This study aims to determine the impact of using gedjet on physical and behavioral development in elementary school children. The method in this study uses a qualitative method with a case study approach. Data obtained through observation and interviews. After the data is collected, then data reduction, data presentation and conclusion are drawn. The conclusions in this study are the occurrence of dependence and addiction which results in laziness in children in activities, disruption of health in terms of physical, and increasingly difficult learning concentration.

Keywords : Impact of Gadgets, Physical and Behavioral Development, Elementary School Children.

Copyright (c) 2022 Siti Rahmi Jalilah

$\triangle$ Corresponding author

Email:20204082021@student.uin-suka.ac.id

DOI $\quad:$ https://doi.org/10.31004/edukatif.v4i1.1716 


\section{PENDAHULUAN}

Perkembangan zaman pada saat ini semakin bertumbuh pesat. Dimana banyak sekali perubahan yang terjadi baik dari bidang pendidikan, teknologi dan sosial. Sehingga dengan perkembangan ini mengubah style kehidupan masyarakat untuk mengikuti arus zaman yang terjadi. Salah satu perubahan perkembangan zaman yanag paling signifikan yaitu pada bidang teknologi atau yang familiar disebut dengan era 4.0 abad 21. Abad 21 ini menjadi salah satu saksi bisu yang mengubah perkembangan hidup manusia yang kian bergantung pada teknologi informasi dan komunikasi yang salah satunya adalah gadget. Gadget merupakan alat elektronik yang mempunyai ukuran relatif kecil terbilang sangat praktis untuk digunakan. Hampir seluruh manusia pada sekarang ini sudah menggunakan gadket. Oleh sebab itu, tidak bisa disangkal bahwa sekarang ini gadget dapat ditemukan diberbagai kalangan baik orang dewasa sampai dengan usia anak-anak, yang kini sudah pandai untuk mendayagunakan teknologi terutama teknologi yang berupa gadget seperti halnya pada handphone ataupun smartphone (Tatminingsih, 2017).

Masa kanak-kanak merupakan masa dimana anak-anak disebut dengan manusia yang "unik" karena memiliki potensi dan perkembang yang relati cepat. Menurut perspektif psikologis, masa muda (anak-anak) juga disebut sebagai usia cemerlang di mana anak-anak dapat mencari cara untuk mengetahui apa yang tidak diketahuinya. Perkembangan merupakan proses yang terjadi dalam diri individu untuk menuju kedewasaan yang meliputi perubahan emosi, pikiran serta kecakapan yang lebih matang. Salah satu pertumbuhan yang dialami oleh manusia adalah pertumbuhan dari segi fisik (biological growth) yaitu pertumbuhan yang terjadi dalam diri individu yang meliputi perubahan pada ukuran tubuh, pertumbuhan pada otak, hormon dan lain sebagainya. Masa perkembangan seorang anak pada aspek biologis berperan penting terlebih pada bidang psikomotor yang berperan amat penting terhadap pertumbuhan dan perkembangan seorang anak masa mendatanag. Pada saat bermain mereka akan mendapatkan keterampilan fisik, keterampilan yang dasar saat membaca, menulis, berhitung serta antar hubungan dengan teman dan keluarga (Fathoni, 2017).

Oleh sebab itu, apabila masa tumbuh kembang seorang anak mulai diserang kecanduan serta terinfeksi oleh pengaruh buruknya dari gadget, maka dampak yang timbulkan adalah terhambatnya perkembangan seorang anak. Dengan demikian penggunaan gadget dengan reting tertinggi ini dimenangkan oleh kalangan anak-anak. Sehingga anak-anak adalah salah satu konsumen yang aktif dalam menggunakan gadget, bagaimana tidak kebanyakan dari anak-anak kita saat ini lebih memperiotaskan bermain gadget dari pada melakukan aktivitasnya dalam kehidupan sehari-hari. Banyak sekali yang suka mengabaikan orang tua terlebih ketika dalam keadaan menyuruh seorang anak, tetapi mereka terfokus hanya pada gadget yang dipegang. Memperihatinkannya seorang anak lupa disekelilingnya ketika mereka sudah terlalu fokus kepada gadget (Al-Ayouby, 2017). Gadget dapat digunakan sebagai sarana untuk dapat menambah segala pengetahuan bagi siswa terlebih dengan kemajuan teknologi saat ini, siswa bisa dikatakan tidak menutup diri mengenai bentuk kemajuan di era globalisasi (Kurniawati, 2020).

Gadget ini adalah alat teknologi yang mempunyai sebuah dampak positif maupun negatif. Akan tetapi, jika diteliti lebih dalam maka faktor yang paling dominan lebih ke arah dampak negatif yang sangat berpengaruh tinggi terhadap perkembangan anak. Sehingga anak seringkali berasumsi bahwa gadget adalah kawan yang selalu ada untuk menemani rutinitasnya sehari-hari. Oleh sebab itu, penggunaan gadget yang berlebihan akan membuat anak merasa introvert dan bahkan ia menganggap hal tersebut adalah sesuatu yang wajib dilakukan. Pada saat ini, banyak sekali seorang anak yang hanya terfokus kepada gadget, sampai melupakan tugas mereka seperti belajar dan sosialisasi dengan lingkungan (Al-Ayouby, 2017). Sejalan dengan sebuah data, dimana Negara Indonesia adalah negara yang cukup tinggi terkait minat dengan sebuah gadget Masalah ini amat sangat menghawatirkan, masa seorang anak sangat identik dengan sifatnya yang masih dikatakan belum stabil dan masih tinggi akan rasa ingin tahu mengenai sesuatu hal. Dampaknya akan terjadi peningkatan terhadap perilaku konsumtif. Dampak lainnya akan berpengaruh terhadap perkembangan anak 
seperti gangguan kesehatan, dan aplikasi-aplikasi lain yang dapat menyebabkan kemalasan untuk belajar. Berangkat dari kasus diatas maka peneliti sangat tertatik untuk meneliti dan meninjau lebih dalam terkait dengan dampak gadget terhadap anak. Harapanya melalui kajian ini peneliti dapat memberikan gambaran yang jelas terkait dampak negatif dari penggunaan gadget.

\section{METODE PENELITIAN}

Jenis penelitian yang diterapkan pada artikel ini berupa penelitian kualitatif dengan menggunakan pendekatan studi kasus. Studi kasus merupakan salah satu bagian dari penelitian kualitatif yang prosedurnya tidak statistik melainkan sebuah gambaran atau analisis mengenai sebuah fenomena, sebuah peristiwa, sosial maupun banyak hal lainnya. Metode penelitian kualitatif ialah metode untuk meneliti sebuah kasus dari suatu kondisi objek ilmiah tertentu yang dimana hasil penelitianya menekankan pada makna dari persitiwa yang terjadi.

Untuk memperoleh informasi dan mendapatkan sebuah data-data yang akurat maka perlu adanya kehadiran peneliti sebagai human instrument. Yang dimana peneliti (human instrument) itu sendiri berfungsi untuk mengumpulkan data dengan cara observasi dan wawancara kepada informan terkait, memilih sendiri subjek penelitian (informan), menentukan fokus penelitian, mengolah dan mengumpulkan data serta menafsirkan data untuk dapat memperoleh kesimpulan atas temuan yang dilakukan.

Subjek penelitian dalam artikel ini ialah ibu Hamidah (wali murid dari salah satu siswa yang diteliti), dan siswa Habib Azim (salah satu siswa sekolah dasar yang diteliti). Penelitian ini dilakukan di satu tempat yang bersifat mendalam yakni hanya di MI NW Nomor 1 Boro' Tumbuh jalan Simpang Kulur desa Tumbuh Mulia Kecamatan Suralaga. Adapun waktu penelitianya dilakukan pada 5 september sampai dengan tanggal 19 september 2021 dengan pengambilan data secara berturut-turut dan fokus penelitiannya yaitu damfak gadget terhadap anak sekolah dasar.

Teknik pengumpulan data dilakukan untuk memperoleh data-data yang lengkap dengan menggunakan metode observasi dan wawancara. Metode observasi ini dilakukan dengan cara mengamati langsung objeknya dan melakukan pencatatan secara sistematis terhadap gejala yang tampak pada obyek penelitian. Observasi ini dilakukan dengan tujuan untuk melihat dan mendeskripsikan situasi sebenarya yang terjadi pada objek yang diteliti. Sedangkan wawancara pada penelitian ini dilakukan oleh peneliti kepada responden yang sekiranya mampu memberikan informasi dari latar belakang masalah yang akan dikaji dengan cara memberikan pertanyaan-pertanyaan yang relevan secara ruling (tatap muka) kepada informan guna untuk memperoleh informasi yang lengkap dan utuh. Dalam melakukan wawancara peneliti menggunakan peralatan yang berupa recorder berjenis smartphone guna untuk merekam hasil wawancara kepada subyek penelitian dan membawa peralatan tulis lainya serta menyiapkan pedoman wawancara.

Selanjutnya data yang diperoleh di analisis dengan cara reduksi data, mengolah data, dan penarikan kesimpulan. Selain dari sumber observasi dan wawancara diatas sumber data yang digunakan dalam penelitian ini juga berupa literatur yang terdiri dari jurnal, buku, artikel atau sumber-sumber dokumen lain yang lebih relavan. Hasil dari pada analisis ini kemudian dikaitkan dengan penelitian sebelumnya yang relevan dengan masalah yang diangkat. Hasil akhir dari penelitian ini berupa laporan tertulis (Creswell, 2016).

Selain itu keabsahan data yang dilakukan dalam penelitian ini juga bertujuan untuk dapat membuktikan apakah penelitian yang dilakukan sudah merupakan penelitian ilmiah, dan sekaligus untuk menguji data yang diperoleh. Keabsahan data yang digunakan berupa trianggulasi yaitu pengecekan data dari berbagai sumber. Trianggulasi itu sendiri dibagi menjadi tiga bagian yaitu pertama, trianggulasi sumber ialah untuk menguji keabsahan suatu informasi yang dilakukan dengan memeriksa informasi yang telah diperoleh melalui beberapa sumber. Kemudian data yang dianalisis tersebut dapat menghasilkan suatu simpulan. Kedua, Trianggulasi tehnik adalah untuk menguji kebenaran data yang telah dilaksanakan dengan tujuan dapat 
mengecek data kepada sumber yang sama dengan teknik yang berbeda melalui tehnik observasi dan wawancara. Ketiga, Trianggulasi waktu yaitu pengecekan keabsahan data dengan cara pengambilan data dalam situasi dan waktu yang berbeda agar dapat memperoleh data yang valid dan kredibel.

\section{HASIL DAN PEMBAHASAN}

\section{Hasil}

Dari hasil penelitian yang didapatkan, diketahui bahwa gedjet adalah salah satu teknologi yang tidak bisa dipisahkan oleh kehidupan manusia terutama pada anak-anak. Sehingga penggunaan gedjet terhadap anak SD sangat berpengaruh terhadap perkembangan fisik serta perilaku yang terjadi dalam diri individu anak tersebut. Dalam menggunakan gadget yang berlebihan dapat menimbulkan anak lupa akan waktu dan rutinitasnya. Sehingga setelah melakukan observasi kebanyakan dari nak-anak menghabiskan waktunya untuk bermain dengan gadget. Seperti yang dilakukan oleh Azim (salah satu anak sekolah dasar yang dapat diteliti ditempat penelitian), setelah menganalisa dapat diambil kesimpulan bahwa setelah pulang dari sekolah sekitar jam 12.00 sampai 14.00 azim tidak langsung mengambil makanan untuk makan siang, namun langsung bermain gadget sebagai pengganti makanan, karena dengan bermain gadget saja sudah membuatnya merasa kenyang. Jam 16.00-17.00 azim kembali bermain gadget, uang jajan yang diberikan oleh orang tuanya yang seharusnya digunakan untuk membeli makanan seperti snack, cilok, es dan sejenisnya namun digunakan untuk membeli voucher internet agar bisa bermain atau mabar dengan teman-temanya. Kemudian setelah selesai mengaji sekitar pukul 19.30 hingga 21.00 azim melakukan kebiasaanya bermain gadget kembali, permainan yang dimainkan memiliki banyak jenis parian seperti halnya bermain mobile lagend, pripayer, dan menonton youtobe. Kondisi tersebut terjadi karena faktor lingkungan dari teman sebayanya, hampir sebagian anak-anak yang berada dilokasi penelitian menggunakan gadget untuk bermain, salah satunya adalah azim. Selain digunakan untuk bermain terkadang gadget digunakan azim untuk mempermudah belajarnya misalnya dalam searching youtobe yang berkaitan dengan cara membaca al-qur'an dengan baik. Dari pantauan peneliti sejauh ini, dari konten edukasi tersebut azim dapat secara langsung mengaplikasikan nada membaca al-qur'an dengan cukup baik. Berdasarkan hasil pengamatan yang didapatkan dari lapangan, penggunaan gadget dapat memberikan dampak yang harus jadi pertimbangan terlebih ketika dikaitkan dengan masa anak-anak.

Setelah melakukan observasi terhadap kasus yang diangkat, selanjutnya penulis melakukan wawancara terhadap ibu Azim. Menurut pengakuanya ia memberikan anaknya hanphone/gadget ketika dalam melakukan pembelajaran daring di masa copid 19 kemarin, karena saat masa copid-19 semua sekolah melakukan pembelajaran jarak jauh termasuk di sekolah dasar. Hingga akhirnya ia memberikan anaknya mengunakan gadget dengan tujuan untuk belajar. Seperti yang diungkapkanya dalam suatu wawancara berikut:

"Disaat masa pandemi kemarin semua jenjang sekolah menganjurkan pembelajaran daring sehingga gadget difungsikan untuk membantu anak dalam melakukan proses pembelajaran, sehingga saya memberikan hanphone kepada anak saya untuk belajar".

Perlu sekiranya orang tua juga memberikan bimbingan, pengawasan serta pembatasan terhadap anak dalam menggunakan gadget agat tidak terjadi introvert pada anak, seperti ungkapan yang di ucapkan oleh narasumber (ibu azim) berikut :

"Anak saya mulai dari pulang sekolah sudah mulai menggunakan gadget, jika handphone itu saya ambil dari tanganya dia akan menangis sehingga saya tidak tega mengambil handphone dari tanganya. Terkadang saya juga tidak bisa mengontrol anak saya karena saya sibuk bekerja di sawah, ya biasalah kalau dikampung rata-rata para orang tua kerjanya disawah. Dengan sering menggunakan gadget anak saya terkadang selalu merasa pusing dan matanyapun sakit. Jika disuruh untuk berhenti bermain gadget dia tidak mau, perilakunyapun berubah kadang kalau di panggil gak nyahut-nyahut, oleh sebab itu saya resah dengan kelakuan anak saya tersebut". 


\section{Pembahasan}

\section{Gadget}

Gadget dalam bahasa inggris mempunyai makna sebuah perangkat elekronik kecil yang mempunyai sebuah fungsi khusus. Gagdet adalah bentuk yang nyata dengan adanya perkembangan ilmu teknologi zaman sekarang dan yang akan datang, yang akan mempengaruhi terhadap cara berpikir manusia dan perilakunya (Alia, 2018). Hal yang membedakan gadget dengan perangkat elektronik lainnya adalah unsur "kebaruan". Adapun yang termasuk dari gadget ialah smartphone, tablet, notebook, dan sebagainya. Seiring dengan cepatnya perkembangan teknologi berupa handphone ini sudah banyak memiliki jenis parian mulai dari handphone yang tanpa kamera sampai dengan yang memiliki beberapa fitur kamera yang canggih didalamnya. Semakain canggih zaman maka semakain canggih pula jenis teknologi yang diciptakan. Hal ini memungkinkan semakin banyak orang yang ingin memiliki dan menggunakannya untuk kebutuhan belajar dan mencari pekerjaan serta informasi yang dibutuhkan. Seperti kenyataan yang ada dilapangan bahwa perkembangan gadget di Indonesia pertumbuhannya cukup begitu pesat. Bahkan peminat gadget di Indonesiapun semakin bertambah dan hampir semua kalangan masyarakat baik dari yang dewasa hingga anakanak gemar menggunakan gadget.

Gadget atau handphone adalah salah satu alat yang tidak bisa terlepas dari kehidupan manusia karena memiliki banyak fungsi serta manfaat yang dapat membantu mempermudah kebutuhan manusia. Adapun manfaat dan fungsi dari gadget itu sendiri adalah pertama, sebagai alat komunikasi, jika pada zaman 90-an manusia masih menggunakan bantuan orang lain untuk menyampaikan informasi, kemudian berkembang lagi melalui tulisan yang berupa surat-suratan yang disampaikan melalui teman. Bentuk manfaat gadget ini tidak lain adalah dapat tersambung dengan internet, para siswa sudah jauh mengenal tentang internet yang secara tidak langsung sering disalahgunakan dan orang tua lah yang harus selalu mengawasi (Ramdhan Witarsa Dkk, 2018). Dan sekarang semua sudah berubah dizaman teknologi atau yang lumrah disebut dengan zaman di era 4.0, karena manusia pada sekarang ini sudah dapat berkomunikasi dengan mudah dan praktis dengan menggunakan handphone dengan berbagai macam parian dan fungsi yang canggih. Kedua, sebagai alat sosial, maksudnya adalah dengan gadget ini kita bisa memperluas pertemanan dengan mudah baik yang didalam maupaun diluar Indonesia, selain itu kita juga bisa berbagi berita dan cerita yang tentunya dapat memberikan manfaat kepada orang lain. Ketiga, sebagai alat bantu dalam dunia pendidikan maksudnya ialah dengan adanya gadget manusia bisa belajar dengan mudah dimanapun dan kapanpun mereka berada tanpa harus ribet membawa setumpuk buku. Selain itu dengan adanya gadget ini kita juga bisa mengakses berbagai macam ilmu pengetahuan yang kita butuhkan sehingga kita tidak perlu susah-susah untuk pergi ke perpustakaan yang mungkin sulit untuk dijangkau. Anak-anak akan lebih cepat menguasai yang namanya gadget dari pada orang tuanya sendiri, maka kiranya perlu para orang tua untuk mengenal dampak negatif dan positif dari gadget itu sendiri (Maya Ferdiana Rozalia, 2017). Penggunaan gadget ini pun dapat mempunyai dampak yang dapat mempengaruhi perilaku sosial seorang anak terlebih dengan lingkungannya (Saniyyah et al., 2021).

Adapun dampak umum dari gadget itu sendiri dibagi menjadi dua bagian yaitu dampak positif dan negatif. Dampak positif diantarnya :

1. Mempermudah individu untuk berkomunikasi

2. Menambah pengetahuan serta wawasan

3. Menambah Teman dengan banyaknya jejaring sosial

4. Munculnya metode-metode baru untuk mempermudah seseorang untuk belajar.

Sedangkan dampat negatif dari gadget itu sendiri yaitu :

1. Merusak syaraf mata.

2. Dapat Mengganggu fungsi pendengaran.

3. Dapat mengubah perilaku seseorang

4. Dapat memberikan efek kecanduan terhadap penggunanya 
5. Mengganggu saat istirahat. Sebagaimana yang telah diungkapkan oleh Mayo Clinic dalam risetnya, ia mengarahkan kita untuk dapat menurunkan kadar cahaya di smartphone kita dengan tingkat lebih rendah supaya tidak menggangu kesehatan mata dimalam hari.

\section{Perkembangan Fisik dan Perilaku}

Perkembangan fisik mempunyai andil yang penting dengan aspek perkembangan yang lain, perkembangan fisik ini adalah sebagai acuan untuk mengetahui pertumbuhan anak (Fitriani \& Adawiyah, 2018). Perkembangan fisik merupakan sesuatu perubahan yang akan terjadi pada manusia. Perubahan yang nampak jelas akan terlihat pada bentuk dan ukuran tubuh manusia dari masa kanak-kanak merupakan masa terpanjang dalam kehidupannya (Winarsih, 2021). Perkembangan fisik adalah terjadinya perubahan pada fisik manusia, seperti adanya perubahan pada tinggi, berat yang membentuk postur tubuh serta adanya pertumbuhan pada tulang, gigi dan otot (Madaniyah et al., 2019). Banyak orang tua yang tidak dengan perkembangan anaknya sendiri, dengan sendirinya mereka tidak tahu mengenai hal tentang kecepatan dan keterlamabatan yang terjadi pada anaknya (Murni, 2017). Perkembangan fisik ini adalah sesuatu yang amat penting bagi anak sekolah dasar, karena pertumbuhan akan mempengaruhi terhadap pola perilaku mereka pada saat proses pembelajaran (Suyadi et al., 2018).

Perkembangan adalah suatu perubahan yang terjadi dalam diri manusia untuk menjadi dewasa. Desmita, Mendefinisikan bahwa perkembangan mencakup adanya perubahan fisik yang terjadi secara terus menerus dari fungsi jasmaniah dan rohaniahnya menuju tahap yang lebih matang. Menurut Mujib dalam Hanafi (2010) perkembangan merupakan suatu perubahan yang dialamai oleh setiap individu yang dimulai dari sejak pembuahan sampai pada akhir kehidupannya. Oleh karena itu perkembangan dapat diartikan sebagai suatu perubahan yang dialami oleh manusia dari sejak kecil sampai menjadi manusia dewasa yang berlangsung secara terstruktur. Ada empat aspek yang mendasari adanya perkembangan fisik seseorang yaitu diantaranya :

a. Perkembangan sebuah kecerdasan dan emosi amat dipengaruhi oleh sistem saraf

b. Otot menjadi bagian terpenting dalam perkembangan kekuatan dan motorisc

c. penyebab munculnya sebuah pola tingkah laku yang baru disebabkan oleh kelenjar Endoktrin, seperti halnya ketika dewasa mulai berkembangnya rasa senang untuk berperan aktif dalam kegiatan yang dimana di dalamnya terdapat lawan jenis

d. bagian-bagian tubuh seperti halnya tinggi, berat dan proporsi.

Sementara itu, Perkembangan biologis (fisik) adalah perkembangan awal untuk menuju perkembangan selanjutnya guna meningkatnya pertumbuhan pada anggota tubuh baik dari segi tinggi dan berta badan, lekukan tubuh serta perkembangan pada otak setiap individu, untuk dapat menjadikannya lebih aktif dari sisi keterampilan fisiknya, serta dapat mengeksplorasi diri terhadap lingkungan sekitar. Adanya pertumbuhan ini tidak lain adalah untuk mematangkan fisik yang ditandai dengan adanya sesuatu yang komplek pada jaringan otot, syaraf dan organ tubuh (Hasanah, 2016).

Perkembangan pada anak merupakan suatu perjalanan kemajuan pada diri anak menuju fase kedewasaan yang berkaitan dengan kemampuan fisik dan mental yang terjadi dalam jangka waktu tertentu. Perkembangan ini bersifat subjektif atau tidak dapat dikomunikasikan dalam angka. Anak usia dini adalah anak yang berada dikelas rendah sekolah dasar yang memiliki perkembangan relatif singkat namun merupakan masa yang sangat penting bagi kehidupannya. Oleh karena itu, pada masa ini seluruh potensi yang dimiliki anak perlu didorong sehingga akan berkembang secara optimal. Anak usia sekolah dasar merupakan anak yang memiliki katagori dengen perubahan yang sangat cepat baik fisik maupun mentalnya.

Perilaku seseorang adalah bentuk wujud dari kepribadian. Perilaku manusia dapat dilihat dari kepribadiannya yang merupakan bagian dari latar belakag hidupnya (Sapara et al., 2020). Perubahan tingkah 
laku merupakan sebuah perubahan yang terjadi atas apa yang sudah dipelajari, baik dengan keluarga, teman sebaya maupun lingkungan dan pada diri masing-masing. Perubahan perilaku manusia dari waktu ke waktu semakin berubah. Hal ini didasari karena perkembangan zaman yang semakin cepat terutama pada perkembangan teknologi. Pendidikan orang tua sangat mempengaruhi perubahan perilaku anak misalnya pendidikan dalam hal mengajari anak bagaimana mengenal dunia teknologi terutama memfungsikan gadget dalam peran pendidikan, gadget tidak hanya berfungssi sebagai alat komunikasi melainkan bisa digunakan untuk mengakses informasi mengenai pelajaran, jadi gadget dapat mempermudah anak untuk belajar dengan mudah yang dimulai dari konten yang memberikan educasi yang positif terhadap perilaku anak seperti belajar bahasa inggris dengan mudah melalui lagu-lagu yang didesain dengan menarik, menghapal ayat-ayat pendek dengan fitur animasi yang unik agar dapat memotivasi proses belajar anak. Oleh sebab itu hal tersebut juga tidak bisa dipisahkan dari pengawasan orang tua untuk dapat membatasi anak dalam menggunkan gadget.

\section{Dampat Gadget terhadap Anak SD}

Berdasarkan hasil observasi dan wawancara yang telah dilakukan, maka dapat ditarik kesimpulan bahwasanya gadget dapat memberikan pengaruh besar terhadap penggunanya. Gadget pada dasarnya diciptakan untuk mempermudah segala bentuk aktivitas manusia dalam hal kebaikan atau yang bersifat positif. Namnun faktanya gadget tidak hanya memberikan dampak positif namun juga berdampak negatif bagi orang yang tidak bisa mengoptimalkan dengan baik. Sehingga pengguanaan gadget tehadap perkembangan fisik dan perubahan perilaku anak pada sekolah dasar memberikan pengaruh besar dan beraneka ragam. Dampak positif yang dapat mempengaruhi perkembangan anak dalam menggunakan gadget yaitu dapat membantu anak untuk belajar dengan mudah, menambah kreaktifitas dan pengetahuan anak. Dari beberapa dampak positif yang diberikan terhadap anak namun dampak negatiflah yang dapat memberikan pengaruh yang lebih dominan terhadap perkembangan anak sekolah dasar yaitu diantaranya:

1) Perubahan perilaku terhadap anak, artinya anak-anak sering tidak menghiraukan perintah orang tua karena terlalu asyik dalam bermain gadget sehingga tidak memperdulikan orang disekitarnya.

2) Malas dalam hal belajar. Setelah bersahabat dengan gadget anak-anak akan merasa enggan untuk belajar karena bermain gadget lebih seru dari pada belajar.

3) Waktu belajar anak akan terganggu serta prestasi menurun.

4) Kecanduan/adiksi, artinya ketergantungan gadget terhadap anak akan menjadikan mereka berasumsi bahwa gadget adalah everything for them. Anak-anak akan merasa galau resah, dan bosan jika harus direnggangkan dengan gadget. Karena Sebagian besar waktu yang ada mereka habiskan untuk bermain gadget. Sehingga akan terdominasi terjadinya miss komunikasi dengan orang tua, dan anak akan cenderung menjadi introvert.

5) Terjadi gangguan terhadap kesehatan termasuk kesehatan pada fisik manusia.

Seperti halnya kasus yang terjadi pada azim karena pengaruh besar dari faktor lingkungan sekitar, yang terjadi pula pada perkembangan fisik seperti pertumbuhan otak yang tidak stabil artinya sebagian dari hidupnya hanya terpikirkan tentang gadget dan permainannya, susah untuk tidur artinya setelah memegang gadget ia terkadang susah untuk beristirahat karena terlalu asyik dalam mengkonsumsinya, terganggunya system syaraf pada otak, gangguan pada mata karena sinar X nya terlalu besar, dan dapat menimbulkan bahanyanya radiasi gadget terhadap daya kembang anak yaitu radiasi dari penggunan gadget yang tergolong gelombang RF. Radiasi RF ini berfungsi untuk memanaskan jaringan yang terdapat dalam tubuh manusia seperti halnya oven microwave yang berfungsi untuk memanaskan makanan. Oleh karena itu dampak dari radiasi ini dapat merusak jaringan pada tubuh karena tubuh yang kita miliki tidak dilengkapi dengan sistem ketahanan untuk dapat mencegah sejumlah panas berlebih akibat radiasi RF. Sehingga ketika radiasi dari alat masuk ke kepala orang dewasa menelan sebanyak 25\%, anak-anak berusia 12 tahun sebanyak setengahnya 
dan yang paling tinggi adalah pada anak-anak berusia 5 tahun, yaitu 75\%. Dengan demikian, bahaya radiasi ini akan lebih besar mempengaruhi anak-anak yang kini menjadi pendamping. dengan perangkat pada periode di bawah 16 tahun (Jonathan, et al. 2015).

Berdasarkan dari beberapa pembahasan serta hasil wawancara diatas seharusnya masa anak-anak adalah masa bermain dan bersosialisasi dengan lingkungan sekitarnya. Tapi faktanya dengan pesatnya perkembangan teknologi informasi dan komunikasi ini menjadikan masa anak-anak terbiasa dalam menggunakan gadget sehingga dapat mengganggu perkembangan psikologis mereka. Tingkat bermain seorang anak-anak Indonesia dikatakan rendah ketika dibandingkan denga negara yang lain, seperti halnya dengan tiga negara baik Jepang, Thailand dan Vietnam. Berdasarkan hasil penelitiannya, sebagian besar anak Indonesia lebih mengabiskan waktu dengan belajar dan menonton TV dan tidak ketinggalan bermain sebuah game (Martsiswati \& Suryono, 2014). Banyaknya para orang tua yang tidak menyadari secara langsung bahwa seorang butuh yang namanya rasa perhatian ketika seorang anak dihadapkan dalam keadaan sedih maupun marah. Maka dampak yang ditimbulkan adalah anak akan menajdi orang yang tertutup dan tidak bisa mengolah emosi dirinya sendiri. Seperti penelitian yang dilakukan oleh Anggrahini, yang mengatakan bahwa dampak lain dari gadget adalah anak akan sulit diajak berkomuniaksi, ketika sudah kecanduan akan gadget (Vira, 2020). Kemudian tidak adanya rasa kepeduliaan ketika diberikan sebuah nasihat. Penelitian lainya mengatakan hampir 94\% para orang tua menjadi responden, mengatakan bahwa penggunaan gadget ini tidak lebih hanya untuk bermain game. Menurutnya anak yang sudah kecanduan akan gadget akan beranggapan bahwa gadget ini adalah bagian yang penting dalam hidupnya (Agustika, 2020). Maka akan menjadi pengganggu ketika bersosialisasi serta kedekatan dengan orang tua maupun dengan temannya.

Maka dari itu, baik buruknya gadget tidak lebih kita sebagai orang tua yang harus selalui mengawasi anak-anak. Seperti dalam penelitian yang dilakukan Denak Sintia Rahmawati tahun 2018 dalam penelitiannya yang berjudul "Analisis Penggunaan Gadget terhadap Akhlak Anak (Studi Kasus di SD N 01 Kebonharjo, Klaten), gadget amat sangat mempunyao pengaruh terhadap perkembangan seorang anak terlebih pada kepribadiannya. Berdampak baik ketika adanya pengawasan orang tua dan berdampak buruk ketika anak diberikan gadget tanpa adanya pengawasan. Dampak positif lainnya adalah tidak ketinggalan akan perkembangan teknologi, dapat juga menghilangkan jenuh ketika belajar dan dampak negatifnya, terkait dengan kesehatan, kurangnya sosialsisasi serta timbulnya males (Rahmawati, 2018).

Melihat dampak-dampak yang terjadi dalam kasus diatas serta beberapa hasil penelitian lain maka perlu adanya pengawasan, bimbingan dan peringatan terhadap anak dalam penggunaan gadget, serta perlunya orang tua melakukan pembatasan waktu untuk anak dalam bermain gadget misalnya tidak lebih dari dua jam per hari. Jika seorang anak diperingati untuk stop bermain gadget namun anak tidak menghiraukan maka tindakan orang tua adalah dapat menyita sementara gadget yang ada ditangan anak tersebut.

\section{KESIMPULAN}

Hasil penelitian ini menunjukkan bahwa pengaruh gadget terhadap anak-anak dapat memberikan efek positif dan negatif. Dan hal yang paling mendasar yang timbul adalah dampak negatif penggunaan gadget terhadap perkembangan fisik dan perilaku pada anak sekolah dasar yaitu diantaranya, keseringan mengabaikan perintah orang tua, terjadinya ketergantungan dan kecanduan yang mengakibatkan kemalasan terhadap anak dalam beraktivitas, terganggunya kesehatan dari segi fisik seperti kurangnya waktu yang digunakan untuk beristirahat, terganggunya sistem syaraf otak pada anak, kelelahan pada mata akibat aspek radiasi yang besar diakibatkan karena sinar $\mathrm{X}$ yang ada di gadget terlalu tinggi, dan konsentrasi belajar semakin berukarang. Adapun dampak positifnya yaitu dapat mempermudah dalam mendapatkan informasi, dapat menambah wawasan, sebagai media untuk belajar sebagai selingan dari buku, mempermudah dalam bersosialisasi. Oleh karenanya Peran orang tua sangat penting dalam membimbing dan berperan aktif untuk 
membantu anak dalam proses perkembangnya. Untuk itu diperlukan pembatasan serta arahan dari orang tua untuk mengawasi anaknya dalam mengoperasionalkan gadget dengan sebaik.

\section{UCAPAN TERIMA KASIH}

Terima kasih saya ucapkan untuk kedua orang tua saya yang selalu memberikan doa-doa baiknya serta semangat setiap waktu untuk menuntut ilmu dalam dunia pendidikan.

\section{DAFTAR PUSTAKA}

agustika, N. L. G. M. W. G. N. S. (2020). Intensitas Penggunaan Gadget Oleh Anak Usia Dini. Jurnal Pendidikan Anak Usia Dini, 8(June), 112-120.

Al-Ayouby, M. H. (2017). Dampak Penggunaan Gadget Pada Anak Usia Dini (Studi Di Paud Dan Tk Handayani Bandar Lampung). Universitas Lampung.

Alia, T. (2018). "Pendampingan Orang Tua Pada Anak Usia Dini Dalam Penggunaan Teknologi Digital." .Journal Of Language, Literature, Culture, And Education Polyglot, 14(1).

Creswell, J. W. (2016). Research Design: Pendekatan Metode Kualitatif, Kuantitatif, Dan Campuran. Pustaka Pelajar.

Fathoni, A. R. (2017). Pengaruh Gadget Terhadap Perkembangan Anak Usia Dini (Diakses 14).

Fitriani, R., \& Adawiyah, R. (2018). Perkembangan Fisik Motorik Anak Usia Dini. Jurnal Golden Age, 2(01), 25. Https://Doi.Org/10.29408/Goldenage.V2i01.742

Hasanah, U. (2016). Pengembangan Kemampuan Fisik Motorik Melalui Permainan Tradisional Bagi Anak Usia Dini. Jurnal Pendidikan Anak, 5(1), 717-733. Https://Doi.Org/10.21831/Jpa.V5i1.12368

Kurniawati, D. (2020). Pengaruh Penggunaan Gadget Terhadap Hasil Belajar Siswa. Edukatif : Jurnal Ilmu Pendidikan, 2(1), 79-84. Https://Edukatif.Org/Index.Php/Edukatif/Article/View/78

Madaniyah, J., Kesuma, U., Istiqomah, K., \& Fisik, P. (2019). Perkembangan Fisik Dan Karakteristiknya Serta Perkembangan Otak Anak Usia Pendidikan Dasar Ulfa Kesuma, Khikmatul Istiqomah 1. Madaniyah, 9(2), 217-236.

Martsiswati, E., \& Suryono, Y. (2014). Peran Orang Tua Dan Pendidik Dalam Menerapkan Perilaku Disiplin Terhadap Anak Usia Dini. Jurnal Pendidikan Dan Pemberdayaan Masyarakat, 1(2), 187. Https://Doi.Org/10.21831/Jppm.V1i2.2688

Maya Ferdiana Rozalia. (2017). "Hubungan Intensitas Pemanfaatan Gadget Dengan Prestasi Belajar Siswa Kelas V Sekolah Dasar." Jurnal Pemikiran Dan Pengembangan Sd, Volume, 5(2).

Murni. (2017). Perkembangan Fisik, Kognitif, Dan Psikososial Pada Masa Kanak-Kanak Awal 2-6 Tahun, Iii(1), 19-33. Https://Jurnal.Ar-Raniry.Ac.Id/Index.Php/Bunayya/Article/Download/2042/1513

Rahmawati, D. S. (2018). Analisis Penggunaan Gadget Terhadap Akhlak Anak (Studi Kasus Di Sd N 01 Kebonharjo, Klaten). Universitas Islam Indonesia.

Ramdhan Witarsa Dkk. (2018). "Pengaruh Penggunaan Gadget Terhadap Kemampuan Interaksi Sosial Siswa Sekolah Dasar.” Pedagogik, 6(1).

Saniyyah, L., Setiawan, D., \& Ismaya, A. (2021). Dampak Penggunaan Gadget Terhadap Perilaku Sosial Anak Di Desa Jekulo Kudus. Edukatif: Jurnal Ilmu Pendidikan, 3(4), 2132-2140.

Sapara, M. M., Lumintang, J., \& Paat, C. J. (2020). Dampak Lingkungan Sosial Terhadap Perubahan Perilaku Remaja Perempuan Di Desa Ammat Kecamatan Tampan'amma Kabupaten Kepulauan Talaud. Jurnal Holistik, 13(3), 1-16. 
Suyadi, Calista, W., \& Puspita, D. (2018). Perkembangan Fisik-Motorik Siswa Usia Dasar: Masalah Dan Perkembangannya. Jurnal Ilmiah Pgmi, 4(2), 170-182.

Tatminingsih, S. (2017). Dampak Penggunaan Tik Terhadap Perilaku Anak Usia Dini, Studi Kasus Pada Anak Usia 4-7 Tahun. Jurnal Pendidikan, 18(1).

Vira, A. (2020). Melalui Penggunaan Gadget Pada Anak Usia Dini 4-6 Tahun.

Winarsih, W. E. (2021). Perkembangan Fisik Anak, Problem Dan Penanganannya. Atthiflah : Journal Of Early

Http://Www.Jurnal.Staidagresik.Ac.Id/Index.Php/Atthiflah/Article/View/126 